38 ( 4 ) : 231 241, 1988

成人急性非リンパ性白血病治療における過多輸血の意義

\author{
论東 雲 正 剛, 土 屋純** \\ *群馬大学医学部第三内科教室（主任：成清卓二教授) \\ **群馬大学医療技術短期大学部
}

(昭和63年 3 月 29 日受付， 5 月12日採択）

序

言

急性白血病に対する寬解導入療法の進歩により， 小児急性リンパ性白血病 (ALL) の初回治療では $90 \%$ 以上の症例が完全寛解となり，5年生存率は $50 \%$ をえ，白血病も根治し得る疾患の一つと見做 されるにいたった。成人急性骨䯣性白血病 (AML) でも完全寛解率は $60 \%$ を越えた。更にこの様な症例 の10〜20\%が化学療法のみで長期生存し得るように なった。しかし，完全寛解に至る過程は決して平坦 ではない. 感染症の併発や出血など多くの問題に遭 遇するのが通例である。一方，極めて稀ではあるが， 感染や輸血などを契機に自然寛解する症例の報告も ある ${ }^{1 \sim 4)}$.これらは白血病の病態の多様性を表現する ものであり，興味深い事実でもある。

近年, 造血幹細胞研究の進歩により, 貧血状態に 対処するため多能性幹細胞から赤血球系細胞への分 化が促進される一方, 過多輸血が顆粒球系細胞や血 小板系細胞への分化を促進することが実験動物では 証明された ${ }^{5 \sim 7}$.「stem cell competition」と呼ばれ るこの現象が，ヒトにも見られるか否かは十分明か でない. 最近小児 ALL の治療過程中過多輸血を行 うと，好中球の回復が早まって感染症の併発率も低 く, 白血病治療に有用であることが指摘された ${ }^{8,9}$. 更に急性白血病では過多輸血に基づく効果が ${ }^{3} \mathrm{H}$ thymidine (TdR) 標識率 $(\mathrm{LI})$ の増加と関連すると の成績が報告され注目されている(10).

これらの報告をふまえて, 急性非リンパ性白血病 (ANLL) 症例に過多輸血を行い, 骨髄芽球の増殖動 態に及ぼす影響を検討したので，その成績を報告す るとともに，過多輸血の白血病治療への応用につき 言及したい。

\section{I 対象及び研究方法}

症例 : 本研究の対象としたのは昭和 54 年 1 月より 昭和 56 年 12 月までの 3 年間に群馬大学医学部附属病 院第三内科, 済生会前橋病院内科抢よび県立ガンセ ンター東毛病院内科に入院した M6を除く未治療 ANLL33例である.うち過多輸血下に寬解導入療法 をおこなったのは，昭和 54 年 12 月から昭和 55 年 10 月 までに入院した全症例17例である(過多輸血群)。こ れら症例の臨床デー夕は表 1 に示した。その前後で 上記の対象期間に入院した症例中から過多輸血を行 うことなく同様の寛解導入療法を実施し, 表 2 に示 した背景因子に有意差を認めなかった16例を選び対 照群とした。なお支持療法は特に規定しなかったが 両群において著差はなかった。

過多輸血の方法と寬解導入療法：過多輸血にはへ モグロビン濃度が $15 \mathrm{~g} / \mathrm{dl}$ をこえるまで赤血球濃厚 液 ( 1 単位約 $130 \mathrm{ml}$ ) を連日 $1 \sim 2$ 単位輸血し, その 後も完全寛解達成までの間へモグロビン濃度が 15 $\mathrm{g} / \mathrm{dl}$ を維持できるように間歇的に輸血した。なおへ モグロビン濃度を $15 \mathrm{~g} / \mathrm{dl}$ 以上に増加させるのに原 則として $7 \sim 10$ 日間を要したが，高齢，発熱，白血 球増多など臨床的諸条件で10日間以上の連日輸血が 困難と思われた症例は，その時点で骨髄白血病細胞 の LI を測定し寛解導入療法に入った。この際へモ グロビン濃度が $15 \mathrm{~g} / \mathrm{d} l$ に達し得なかった症例は 2 例で, 到達最高值は各々 $13.3 \mathrm{~g} / \mathrm{dl}$ と $13.9 \mathrm{~g} / \mathrm{dl}$ であ り, これら 2 例では寛解導入療法期間中は $13.3 \mathrm{~g} / \mathrm{dl}$ $\sim 15.9 \mathrm{~g} / \mathrm{dl}$ に維持できた。 その他の 15 例における過 多輸血期間中の最高へモグロビン濃度は $20.7 \mathrm{~g} / \mathrm{dl}$ で各例の最高值の平均は $17.4 \pm 1.5 \mathrm{~g} / \mathrm{dl}$ であり, 全例 で治療期間中は $13 \mathrm{~g} / \mathrm{dl}$ 以上を維持できた。 なお大部 分の症例では更に寛解判定時点に至るまで $12 \mathrm{~g} / \mathrm{dl}$

认論文別刷請求先 广371 前橋市昭和町三丁目 $39-22$

群馬大学医学部第三内科学教室

東 雲 正 剛 
Table 1 Pretreatment Features of Cases With Non-Lymphocytic Leukemia in Hypertransfusion Group

\begin{tabular}{|c|c|c|c|c|c|c|c|c|c|c|c|c|}
\hline \multirow{2}{*}{\multicolumn{2}{|c|}{ Patient }} & \multirow[b]{2}{*}{ Sex } & \multirow[b]{2}{*}{ Age } & \multirow[b]{2}{*}{ FAB } & \multicolumn{4}{|c|}{ Peripheral Blood } & \multicolumn{3}{|c|}{ Bone Marrow } & \multirow[b]{2}{*}{$\mathrm{CR}$} \\
\hline & & & & & $\begin{array}{l}\mathrm{Hb} \\
\mathrm{g} / \mathrm{dl}\end{array}$ & $\begin{array}{c}\text { Reticulocytes } \\
\% 0_{0}\end{array}$ & $\begin{array}{c}\mathrm{WBC} \\
/ \mu \mathrm{l} \\
\end{array}$ & $\begin{array}{c}\text { PLT } \\
\times 10^{4} / \mu 1 \\
\end{array}$ & $\begin{array}{c}\mathrm{NCC} \\
\times 10^{4} / \mu \mathrm{l} \\
\end{array}$ & $\begin{array}{c}\text { Blasts } \\
\%\end{array}$ & $\begin{array}{l}\mathrm{LI} \\
\%\end{array}$ & \\
\hline 1 & I. N. & M & 17 & M 1 & $5.3(19.6)^{*}$ & 1 & 8800 & 2.6 & 40.0 & 97.6 & $7.2(20.3)^{*}$ & + \\
\hline 2 & R. S. & M & 61 & M 2 & $9.2(15.2)$ & 10 & 2000 & 3.8 & 13.9 & 85.8 & $3.5(5.4)$ & + \\
\hline 3 & E.M. & M & 46 & M 2 & $8.7(18.1)$ & 36 & 1100 & 15.9 & 4.7 & 68.8 & $5.4(\mathrm{ND})$ & + \\
\hline 4 & T. S. & $\mathrm{M}$ & 33 & M 2 & $8.1(16.9)$ & 19 & 2600 & 6.7 & 7.5 & 43.2 & $4.5(7.7)$ & + \\
\hline 5 & R. I. & $\mathrm{M}$ & 74 & M 4 & $9.7(16.9)$ & 25 & 5200 & 3.6 & 35.0 & 51.8 & $7.2(12.4)$ & + \\
\hline 6 & G.S. & M & 68 & M 4 & $11.5(18.6)$ & 0 & 5600 & 2.0 & 18.0 & 63.6 & $5.4(2.6)$ & + \\
\hline 7 & M. K. & $\mathrm{F}$ & 12 & M 1 & $12.4(16.5)$ & 16 & 4700 & 32.4 & 74.0 & 95.4 & $11.5(16.2)$ & + \\
\hline 8 & S.M. & $\mathrm{F}$ & 29 & M 1 & $6.8(15.3)$ & 2 & 11500 & 2.8 & 23.0 & 87.0 & $16.0(13.6)$ & - \\
\hline 9 & K. Y. & $\mathrm{F}$ & 61 & M 2 & $6.5(16.0)$ & 2 & 6300 & 1.4 & 17.0 & 94.4 & $6.0(\mathrm{ND})$ & - \\
\hline 10 & Y. U. & M & 63 & M 4 & $5.5(15.2)$ & 39 & 600 & 19.5 & 12.2 & 47.6 & $3.8(3.8)$ & - \\
\hline 11 & K. I . & M & 38 & M 1 & $8.9(15.8)$ & 4 & 9000 & 1.7 & 27.0 & 95.4 & $12.3(14.4)$ & - \\
\hline 12 & F. N. & $\mathrm{F}$ & 60 & M 4 & $6.2(15.9)$ & 19 & 7900 & 5.8 & 14.3 & 51.0 & $11.6(11.0)$ & - \\
\hline 13 & K. K. & $\mathrm{M}$ & 76 & M 2 & $4.5(17.3)$ & 8 & 3500 & 1.0 & 10.0 & 57.0 & $5.2(5.9)$ & - \\
\hline 14 & I . K. & $\mathrm{M}$ & 51 & M 5 & $9.9(15.7)$ & 0 & 5900 & 1.0 & 15.0 & 87.0 & $\mathrm{ND}(1.4)$ & - \\
\hline 15 & K. N. & F & 55 & M 2 & $8.1(15.0)$ & 63 & 2100 & 17.2 & 12.0 & 66.6 & $4.8(3.8)$ & + \\
\hline 16 & T. A. & $\mathrm{F}$ & 52 & M 5 & $5.8(13.3)$ & 17 & 6800 & 7.7 & 26.1 & 86.2 & $14.2(8.6)$ & - \\
\hline 17 & T.M. & M & 76 & M 5 & $3.1(13.9)$ & 10 & 800 & 11.4 & 7.4 & 87.4 & $13.0(6.5)$ & + \\
\hline \multicolumn{2}{|c|}{ Mean } & \multicolumn{3}{|c|}{51.3} & $7.7(16.2)$ & 15.9 & 4964.7 & 8.0 & 21.0 & 74.5 & $8.2(8.9)$ & \\
\hline & $\pm \mathrm{SD}$ & \multicolumn{3}{|c|}{19.7} & $2.5(1.6)$ & 17.0 & 3210.7 & 8.7 & 16.8 & 19.1 & $4.1(5.5)$ & \\
\hline
\end{tabular}

* ( ) : after hypertansfusion.

ND, not done ; FAB, French-American-British classification ;

NCC, nucleated cell count ; LI, labeling index ; CR, complete remission

Table 2 Comparison of Various Background Factors Between Hypertransfusion and Control Groups.

\begin{tabular}{lccc}
\hline & $\begin{array}{l}\text { Hypertransfusion } \\
\text { Group }\end{array}$ & $\begin{array}{l}\text { Control } \\
\text { Group }\end{array}$ & P Value \\
\hline Number of patients & 17 & 16 & \\
Age $(\mathrm{yrs})$ & $51.3 \pm 19.7$ & $44.8 \pm 14.1$ & $0.2<\mathrm{P}<0.3$ \\
Sex $(\mathrm{M}: \mathrm{F})$ & $11: 6$ & $8: 8$ & $\mathrm{NS}$ \\
\hline Peripheral blood & & & \\
WBC $(/ \mu \mathrm{l})$ & $4964.7 \pm 3210.7$ & $6225 \pm 3315.7$ & $0.2<\mathrm{P}<0.3$ \\
Blasts $(/ \mu \mathrm{l})$ & $2383.7 \pm 2798.9$ & $3872.7 \pm 3701.4$ & $0.2<\mathrm{P}<0.3$ \\
Hb $(\mathrm{g} / \mathrm{dl})$ & $7.7 \pm 2.5$ & $8.0 \pm 1.9$ & $0.5<\mathrm{P}$ \\
PLT $\left(\times 10^{4} / \mu 1\right)$ & $8.0 \pm 8.7$ & $5.2 \pm 4.2$ & $0.2<\mathrm{P}<0.3$ \\
\hline Bone marrow & & & \\
NCC $\left(\times 10^{4} / \mu \mathrm{l}\right)$ & $21.0 \pm 16.8$ & $32.9 \pm 34.6$ & $0.2<\mathrm{P}<0.3$ \\
Blasts $(\%)$ & $74.5 \pm 19.1$ & $82.8 \pm 14.7$ & $0.1<\mathrm{P}<0.2$ \\
\hline
\end{tabular}

mean \pm SD

NS : not significant 
以上を維持した。

寛解導入療法: 宇塚 ${ }^{11}$ の二段法変法に従う DCMP 療法 ${ }^{12)}$ 又は BHAC-DMP 療法 ${ }^{13)}$ によった。 その要点は以下の通りである. cytosine arabinoside (Ara-C) は $80 \mathrm{mg} / \mathrm{m}^{2} /$ 日を 1 日 2 回 $2 \sim 4$ 時間かけ て, behenoyl Ara-C (BH-AC) は $170 \mathrm{mg} / \mathrm{m}^{2} /$ 日を 1 日 1 回 3 時間かけていずれも毎日 7 日〜 14 日間点滴 静注した. 6-mercaptopurine (6-MP) 及びprednisolone は各々 $80 \mathrm{mg} / \mathrm{m}^{2} /$ 日, $20 \mathrm{mg} / \mathrm{m}^{2} /$ 日を毎日経口 投与した。投与期間は Ara-C 又は BH-AC のそれ と一致し, 骨髄有核細胞数 $15,000 / \mu 1$ 以下，末梢白 血球数 $1,200 / \mu 1$ 以下の target point (A) に到達する までとした。この間 daunorubicin( DNR) $25 \mathrm{mg} / \mathrm{m}^{2} /$ 日を適宜投与した. 治療効果の判定は木村の基準 ${ }^{14)}$ によった。寛解導入に失敗した症例中 2 例は BHAC-DMP に vincristine $2 \mathrm{mg} /$ 日 $\times 1$ / 週を加え て投与した。完全寬解例に対しては寬解導入に用い たと同じレジメンで 7 日間，この間に daunorubicin $15 \sim 25 \mathrm{mg} / \mathrm{m}^{2} /$ 日を 2 回投与する寛解強化療法を 2 $\sim 3$ 週間隔で原則として 3 回実施した. 以後は既報 した方法 ${ }^{15}$ に準じて6-MP/Ara-C により 5 年間に わたり維持療法をおこなった。

骨髄芽球の ${ }^{3} \mathrm{H}-\mathrm{TdR}$ 標識率 (LI) の測定 : 過多輸 血群では過多輸血前と寛解導入療法直前 (以後過多 輸血後と表現) に, 対照群では寛解導入療法前に骨 髄中の芽球の LI を測定した。過多輸血群で輸血開 始前に LI を測定できたのは16例, 過多輸血後に LI を測定できたのは15例，両者で LI を測定できたの は14例であった。対照群では 7 例で測定できた。LI の測定は既報の方法 ${ }^{16)}$ を用いた。即ち, ヘパリン加骨 髄穿刺針で得られた骨髄有核細胞 $2.5 \times 10^{7}$ 個に Eagle MEM 液体培地を加え $4.5 \mathrm{ml}$ とし, $37^{\circ} \mathrm{C} 15$ 分 間卯孚置後, 最終濃度 $0.5 \mu \mathrm{Ci} / \mathrm{ml}$ になるように ${ }^{3} \mathrm{H}-\mathrm{TdR}$ (specific activity $5 \mathrm{Ci} / \mathrm{m}$ mol, The Radiochemical Centre, Amersham) を加えて,さらに 1 時間睬置し た. 次に冷生理食塩水で 5 回洗浄し, 沈渣の塗沫標 本を作り乾燥し, メタノール固定後,「さくら」NRM 2 乳剤を使用して dipping 法で autoradiogram

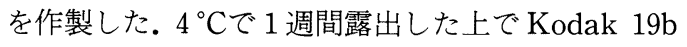
現像液で現像し, 定着, 水洗乾燥後 Giemsa 染色を 施し検鏡した. background は有核細胞 1 個当たり 1 個以内であったので核上に限局した銀顆粒が 4 個 以上あれば標識細胞と判定した。骨髄芽球1,000個を 数えて標識率を求め百分比として表現した.
過多輸血による血液像の変動：過多輸血による末 梢血液像, すなわち成熟顆粒球数や血小板数の変動 を全例で, 成熟顆粒球や血小板の nadir からの回復 は完全寛解に到達した過多輸血群 9 例で検討し, 非 過多輸血群の結果と比較した。

統計：寛解期間と生存期間は Kaplan-Meier 法に より求め, 有意差検定は $\mathrm{t}$ 検定, $\chi 2$ 検定または Generalized Wilcoxon test により施行した。

\section{II成績}

I 過多輸血による諸データの変動

(1) 過多輸血による血液像の変化

過多輸血群17例を対象として過多輸血前後の末梢 血液像および骨髄像の変化を図 1 に示した。へモグ ロビン濃度は有意に上昇し $(\mathrm{p}<0.01)$, 末梢網赤血 球数は低下した（p<0.01）ものの末梢白血球総数, 白血病細胞数, 成熟顆粒球数, 血小板数のいずれに おいても有意の変動を認めなかった。骨髄像では白 血病細胞比率に変化はなかったが, 赤芽球比率は有 意に減少した $(\mathrm{p}<0.02)$.

(2) 骨髄芽球の LI

結果は表 1 と図 2 に示した. 過多輸血前の LI 平 均值士SD は，16例では $8.2 \pm 4.1 \%$ であり過多輸血 後の 15 例では $8.9 \pm 5.5 \%$ で両者間に有意差はなかっ た。対照群16例中 LI を測定できたのは 7 例でその 平均值 $\pm \mathrm{SD}$ は $6.3 \pm 3.5 \%$ であった。この值と過多 輸血群の輸血前の LI 平均値との間には有意差を認 めなかった。過多輸血前後の 2 回 LI 測定値が得ら れた14例に於て両者を比較したところ, 過多輸血後 LI が減少または不変であったのは 7 例, 過多輸血後 LI が増加したのは 7 例でうち 2 例では増加が顥著 であった。これらはI. N.例およびR.I.例で，FAB 分類 ${ }^{17)}$ ではそれぞれ，M 1 およびM 4 であった。図 3 に I. N. 例を代表として過多輸血前後の骨髄芽球の 核直径と LI との関係を示した．図上り明らかな如 く過多輸血により ${ }^{3} \mathrm{H}-\mathrm{TdR}$ 標識率の高い大型芽球 の増加が明かであった。他の症例でも類似の変化を 示すものが多かった．尚，過多輸血後 LI が $4.5 \%$ か ら7.7\%に増加した T. S. 例は再発することなく現 在 5 年間生存中である.

(3) LI と血液, 骨髄像との関係

過多輸血前後で LI が増加した 7 例と減少または 不変であった 7 例に分けて過多輸血前後の血液, 骨 髄像の変化を検討した。この成績は図 1 に示した通 

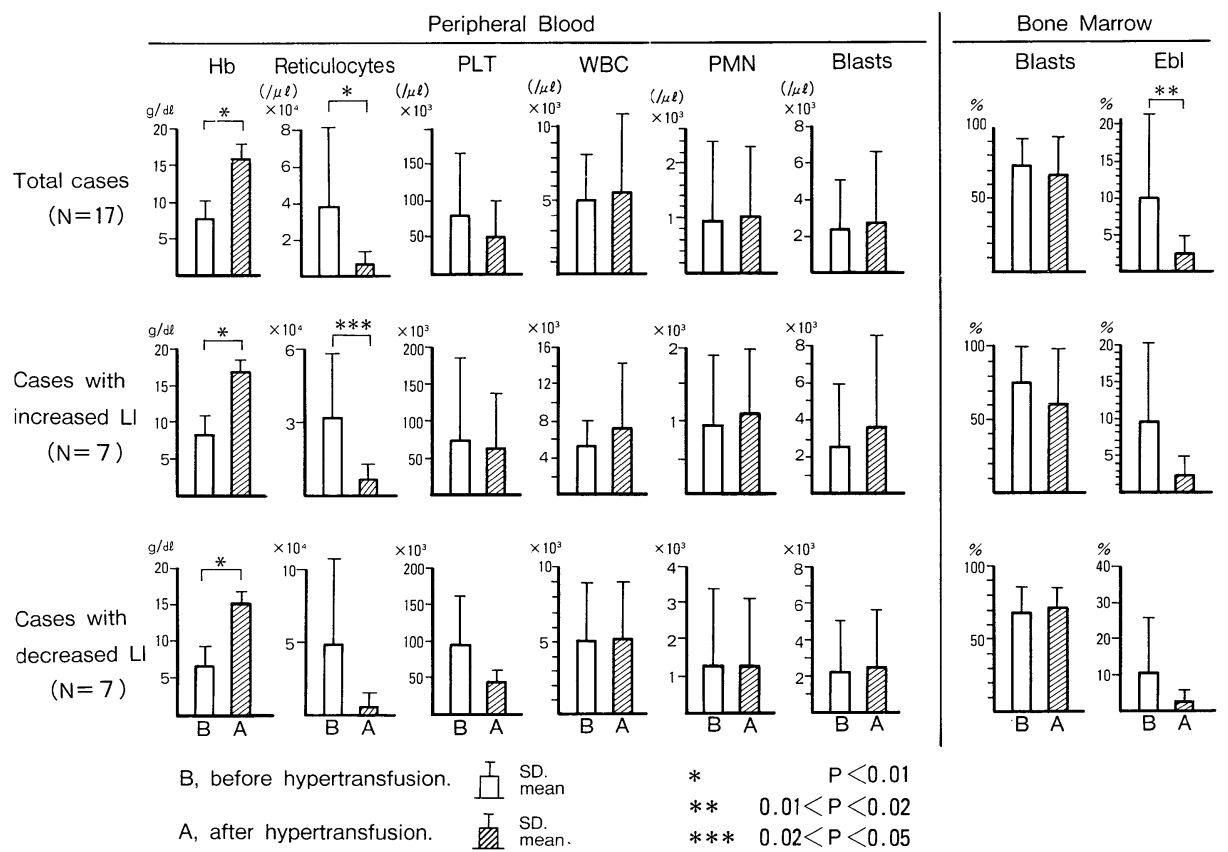

Fig 1 Summary of Hematological Data in 17 Patients of Hypertransfusion Group Befor and After Hypertransfusion.

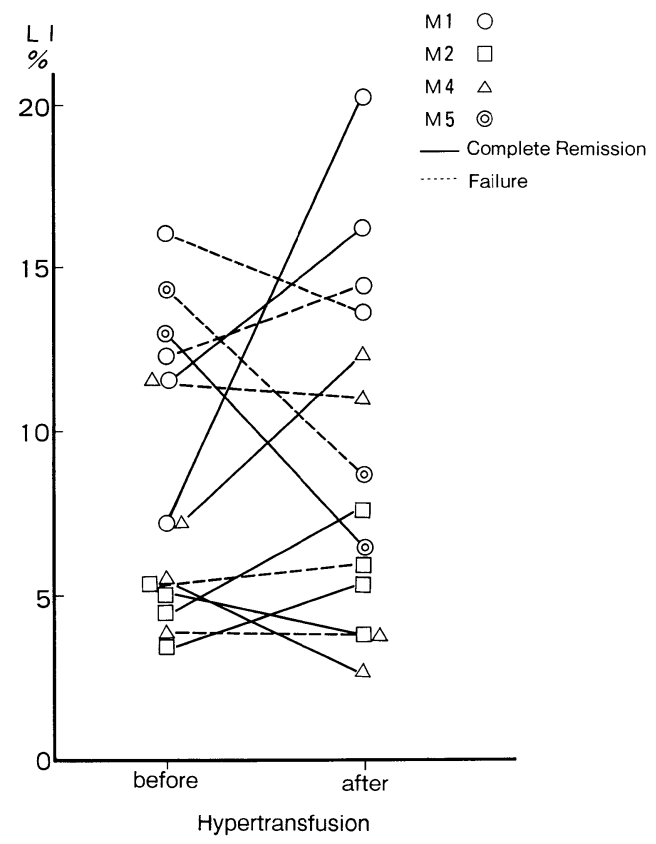

Fig $2 \quad{ }^{3} \mathrm{H}-\mathrm{TdR}$ Labeling Indices of Leukemic Blasts Before and After Hypertransfusion

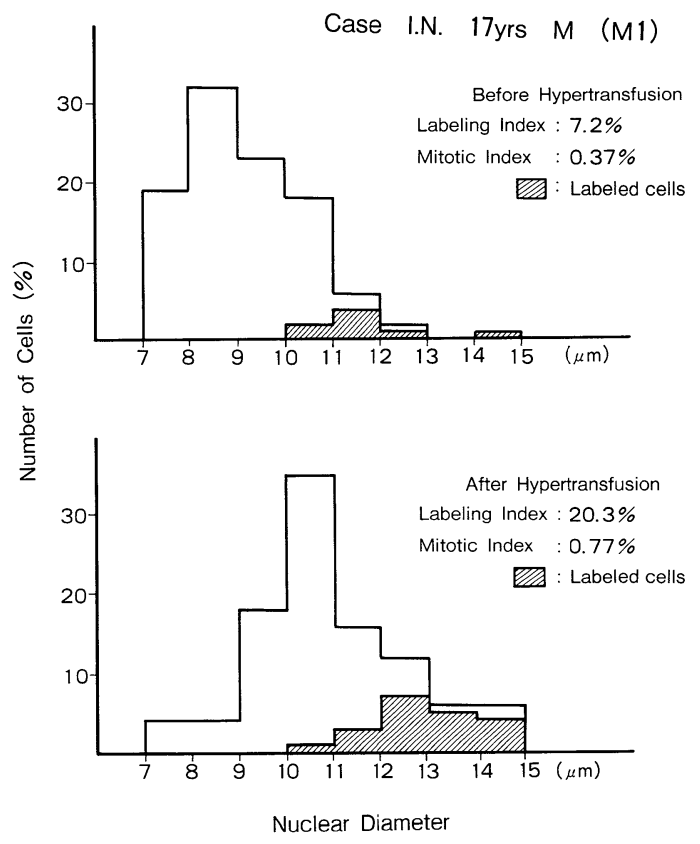

Fig 3 Nuclear Diameter and ${ }^{3} \mathrm{H}-\mathrm{TdR}$ Labeling Index of Leukemic Blasts Before and After Hypertransfusion 
りで両者間に有意差を認めなかった。

\section{II 過多輸血症例の治療成績}

(1) 寛解導入率

過多輸血後に寛解導入療法を実施した 17 例中完全 寛解は 9 例 $52.9 \%$ ，部分寛解は 1 例 $5.9 \%$ であった。 寛解導入療法開始後 7 日以内の早期死亡のため評価 不能となったのは 3 例であった。 その死因は敗血症 の疑い 1 例, 脳出血 2 例であった.これに対して対 照群16例では完全寛解13例 (81.3\%), 部分寛解 0 例 $(0 \%)$, 評価不能 1 例であった. 評価不能は早期死 亡であり，その死因は脳出血であったが，同時に高 熱を示し敗血症の併発が疑われた。評価不能例の発 現率には過多輸血群と対照群間に有意差はなく, 早 期死亡例の死因も出血, 感染が主で著差はなかった。 評価不能例を除いた完全寬解率は過多輸血群 64. $3 \%$, 対照群 $86.7 \%$ となり, 両群間に有意差はなかっ た.

\section{(2) 寬解期間及び生存期間}

初回治療後完全寛解を達成出来た過多輸血群 9 例 と対照群13例の寛解期間並びに生存期間を KaplanMeier 法により図 4 に示した。 50\%寛解期間はそれ ぞれ19ケ月と 14 ケ月，抗白血病治療開始後50\%生存 期間はそれぞれ 28 ケ年 24 ケ月で，いずれにも両群 間で有意差は見られなかった。過多輸血群と対照群 のそれぞれ 2 例と 3 例が 5 年以上生存した。それは 寛解例のそれぞれ $22 \%$ と $23 \%$, 全症例の $11.8 \%$ と 18. 8\%に該当したが，いずれにおいても有意差はなかっ た.うち 2 例宛が昭和 62 年 7 月現在も生存中である.

(3) LI と治療成績一過多輸血群

過多輸血群においてその前後の LI が増加した 7 例と, 減少及び不変であった 7 例に分けて寛解導入 療法の効果を比較検討した. LI 増加群では評価不能 例はなく， 5 例 $71.4 \%$ で完全寛解に到達した。これ に対して減少群では評価不能が 2 例あり, これを加 えた場合完全寬解率は 3 例 $42.9 \%$ となり完全寛解率 は増加群に比し低值であった。しかし評価不能例を 除外すると完全寛解率は $60 \%$ となり, LI の上下間で の差はなくなった。

(4) LI と治療成績一対照群

対照群16例中 LI を測定できた 7 例を対象として 治療効果との関連を検討した。完全寛解に到達した 5 例の LI 平均值は $5.1 \pm 3.3 \%$ であった。寛解導入 に失敗した 2 例の LI は $7.6 \%$ お よ゙゙10.7\%であっ た。
50\% Survival Duration (Kaplan-Meier)
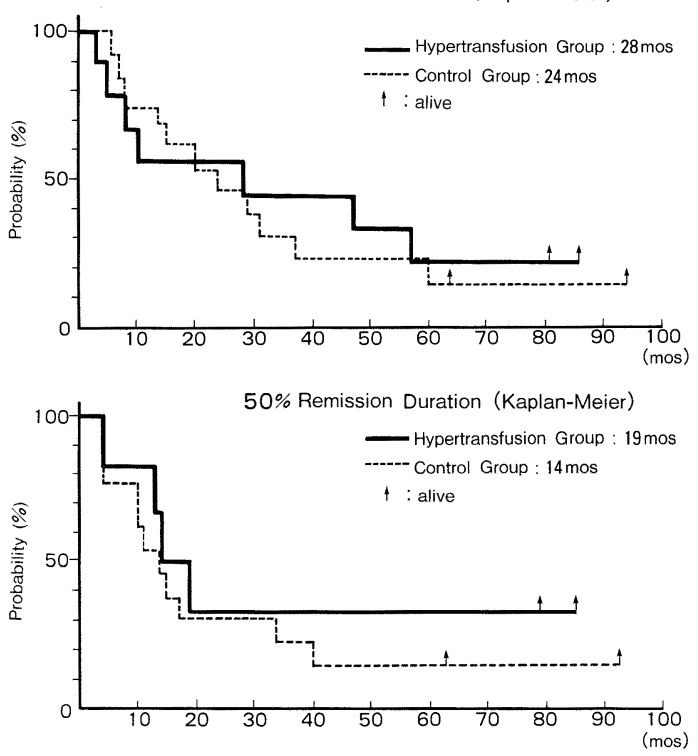

Fig 4 Durations of Complete Remission and Survival in Patients Achieving CR

III寛解に関する検討

完全寛解 (CR) に到達した過多輸血群 9 例と対照 群13例につき，寛解に到達するまでの平均日数を表 3 に示した，過多輸血群ではへモグロビン濃度が 15 $\mathrm{g} / \mathrm{d} 1$ 以上に達するまでに平均 $7.8 \pm 1.7$ 日を要し, 治 療の開始は対照群に比し平均 $12.3 \pm 3.5$ 日遅延した。 寛解導入療法後 Target point (A) に達する期間の 平均值は, 対照群に比して過多輸血群がやや長く, 寬解に到達した症例間での差は有意でなかったがよ り顕著となった。この間に投与された平均 daunorubicin (DNR) 量は過多輸血群全体として比較して も, また寛解例間で比較しても対照群に比し少量で あった. 他方寛解導入療法開始後, 成熟顆粒球数や 血小板数が nadir に達するまでの期間には有意差は なかったとはいえ, 過多輸血群特に寛解例でより長 い傾向があり，就中過多輸血後 LI 増加寛解例では その傾向が明かであった。寛解例についての比較で は寛解導入療法開始より完全寛解到達までの期間に も過多輸血，対照両群間に有意差はみられなかった ものの過多輸血群では対照群に比して長い傾向が あった。これに対し有熱期間平均値は過多輸血群中 LI 増加例で短い傾向がみられた。寛解到達までの期 間に対する有熱期間の比率 (有熱率) は過多輸血群 で低值の傾向が明らかであった。 
Table 3 Clinical Courses to Achieve Complete Remission.

\begin{tabular}{|c|c|c|c|c|c|c|c|c|c|}
\hline & \multirow{2}{*}{$\begin{array}{l}\text { Number } \\
\text { of } \\
\text { Patients }\end{array}$} & \multicolumn{2}{|c|}{ to Target Point } & \multicolumn{2}{|c|}{ Days to Nadir } & \multicolumn{3}{|c|}{ to Achieve $\mathrm{CR}$} & \multirow{2}{*}{$\underbrace{\text { Febrile Days* }}_{\text {Days to } \mathrm{CR}}$} \\
\hline & & Days & $\mathrm{DNR}(\mathrm{mg})$ & WBC & PLT & Days & $\begin{array}{c}\text { Total DNR } \\
\text { (mg) }\end{array}$ & $\begin{array}{c}\text { Febrile Days } \\
\left(>38^{\circ} \mathrm{C}\right)\end{array}$ & \\
\hline \multicolumn{10}{|c|}{ Hypertransfusion group } \\
\hline A : total cases & 17 & $9.5 \pm 4.6$ & $101.9 \pm 46.7$ & $16.8 \pm 4.1$ & $15.4 \pm 5.4$ & & & $12.9 \pm 9.4^{* *}$ & \\
\hline $\mathrm{B}: \mathrm{CR}$ cases & 9 & $11.3 \pm 4.0$ & $105.6 \pm 45.0$ & $17.0 \pm 4.4$ & $16.9 \pm 6.2$ & $60.9 \pm 36.1$ & $215.6 \pm 195.5$ & $13.1 \pm 10.0$ & $0.25 \pm 0.16$ \\
\hline $\begin{array}{c}\mathrm{C}: \text { CR cases with } \\
\text { increased } \mathrm{LI}\end{array}$ & 5 & $13.8 \pm 2.2$ & $122.0 \pm 49.7$ & $18.8 \pm 5.2$ & $19.8 \pm 6.9$ & $53.0 \pm 33.7$ & $160.0 \pm 97.5$ & $9.0 \pm 6.2$ & $0.25 \pm 0.22$ \\
\hline \multicolumn{10}{|l|}{ Control group } \\
\hline $\mathrm{D}:$ total cases & 16 & $8.9 \pm 3.2$ & $148.7 \pm 72.7$ & $15.5 \pm 7.8$ & $13.5 \pm 6.2$ & & & $13.5 \pm 6.8^{* *}$ & \\
\hline $\mathrm{E}: \mathrm{CR}$ cases & 13 & $9.0 \pm 3.2$ & $163.1 \pm 66.1$ & $15.5 \pm 7.8$ & $13.5 \pm 6.2$ & $38.5 \pm 13.4$ & $229.2 \pm 145.9$ & $13.5 \pm 6.8$ & $0.35 \pm 0.11$ \\
\hline \multicolumn{10}{|l|}{ P Value } \\
\hline$A: B$ & & $0.3<\mathrm{P}<0.4$ & $0.5<\mathrm{P}$ & $0.5<\mathrm{P}$ & $0.5<\mathrm{P}$ & & & $0.5<\mathrm{P}$ & \\
\hline$A: D$ & & $0.5<\mathrm{P}$ & $0.02<\mathrm{P}<0.05$ & $0.5<\mathrm{P}$ & $0.3<\mathrm{P}<0.5$ & & & $0.5<\mathrm{P}$ & \\
\hline $\mathrm{B}: \mathrm{E}$ & & $0.1<\mathrm{P}<0.2$ & $0.02<\mathrm{P}<0.05$ & $0.5<\mathrm{P}$ & $0.2<\mathrm{P}<0.3$ & $0.1<\mathrm{P}<0.2$ & $0.5<\mathrm{P}$ & $0.5<\mathrm{P}$ & $0.05<\mathrm{P}<0.1$ \\
\hline $\mathrm{C}: \mathrm{E}$ & & $0.001<\mathrm{P}<0.01$ & $0.2<\mathrm{P}<0.3$ & $0.3<\mathrm{P}<0.4$ & $0.05<\mathrm{P}<0.1$ & $0.4<\mathrm{P}<0.5$ & $0.3<\mathrm{P}<0.4$ & $0.2<\mathrm{P}<0.3$ & $0.1<\mathrm{P}<0.2$ \\
\hline
\end{tabular}

Table 4 Recovery from Nadir of Mature Granulocytes and Platelets in Cases Achieving CR

\begin{tabular}{|c|c|c|c|c|c|c|c|}
\hline & \multirow{2}{*}{$\begin{array}{c}\text { Number } \\
\text { of } \\
\text { Patients }\end{array}$} & \multicolumn{3}{|c|}{ Days for a PMN Count to Reach } & \multicolumn{2}{|c|}{$\begin{array}{c}\text { Days for a Platelet } \\
\text { Count to Reach }\end{array}$} & \multirow{2}{*}{$\begin{array}{l}\text { Days for Recovery } \\
\text { of a Reticulocyte } \\
\text { Count }\end{array}$} \\
\hline & & 500 & 1000 & $1500(/ \mu 1)$ & 3 & $10\left(\times 10^{4} / \mu 1\right)$ & \\
\hline \multicolumn{8}{|c|}{ Hypertransfusion group } \\
\hline $\mathrm{B}: \mathrm{CR}$ cases & 9 & $8.7 \pm 3.6$ & $12.0 \pm 3.3$ & $14.0 \pm 4.1$ & $8.1 \pm 3.9$ & $15.1 \pm 5.8$ & $21.4 \pm 15.6$ \\
\hline $\begin{array}{c}\mathrm{C}: \text { CR cases with } \\
\text { increased LI }\end{array}$ & 5 & $10.2 \pm 2.4$ & $13.2 \pm 3.8$ & $15.6 \pm 4.7$ & $6.8 \pm 2.7$ & $12.5 \pm 4.2$ & $27.3 \pm 23.1$ \\
\hline \multicolumn{8}{|l|}{ Control group } \\
\hline $\mathrm{E}: \mathrm{CR}$ cases & 13 & $8.7 \pm 4.3$ & $12.3 \pm 4.5$ & $15.6 \pm 5.4$ & $9.8 \pm 4.1$ & $15.7 \pm 7.7$ & $15.5 \pm 5.6$ \\
\hline \multicolumn{8}{|l|}{$\mathrm{P}$ Value } \\
\hline$B: E$ & & $0.5<\mathrm{P}$ & $0.5<\mathrm{P}$ & $0.4<\mathrm{P}<0.5$ & $0.3<\mathrm{P}<0.4$ & $0.5<\mathrm{P}$ & $0.3<\mathrm{P}<0.4$ \\
\hline $\mathrm{B}: \mathrm{C}$ & & $0.4<\mathrm{P}<0.5$ & $0.5<\mathrm{P}$ & $0.5<\mathrm{P}$ & $0.1<\mathrm{P}<0.2$ & $0.4<\mathrm{P}<0.5$ & $0.4<\mathrm{P}<0.5$ \\
\hline
\end{tabular}

成熟顆粒球の nadir からの回復には過多輸血群と 対照群との間に有意差を認めなかったが，血小板の 回復期間は 3 万までも 10 万までもいずれも過多輸血 群で短く LI 増加宽解例では対照群寛解例に比し短 い傾向が窥われた。他方網赤血球出現までの平均期 間は有意差はなかったものの過多輸血群で長い傾向 がみられた（表4）。

\section{考察}

細菌やウィルス感染を契機として急性白血病が自 然寛解することは古くから報告されている。他方， その様な誘因がなく輸血が寛解へ導入したと考えざ るを得ない症例も報告されている ${ }^{18)}$. 寛解でなくと
も輸血が臨床症状や肝脾腫など臨床症候を改善 し ${ }^{19)}$, 生存期間を延長すること20)も指摘されている.

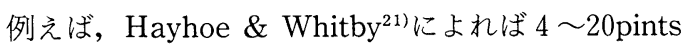
の全血輸血を受けた成人急性白血病41例では14例が 血液学的に改善され, うち 5 例が $2 \sim 6$ ケ月間続く 寛解に到達したという。輸血による治療効果の発現 機序は種々推論されているが20,21), 造血機構が殆ど 解明されていなかった頃のことであり現在参考とな ることは少ない. その後造血系における幹細胞と体 液性調節機構の存在が実証されるに及んで, これら の問題に新なる観点から検討が加えられる様になっ た。過多輸血によるへモグロビン濃度の上昇は赤血 球系造血を抑制し, CFU-C 増加を介し顆粒球数を増 
加するのみではなく ${ }^{5,6)}$ ，血小板数をも増やすとい $う^{77}$. かくて過多輸血下にエックス線照射を受けた マウスは対照マウスに比し顆粒球系の回復が促進さ れることが指摘された ${ }^{5}$. 他方, 過多輸血動物におけ る顆粒球系及び血小板系造血の元進はエリトロポエ チン投与により阻止される7).これらの成績は過多 輸血が多能性造血幹細胞から赤血球系造血幹細胞へ の分化を抑制し，顆粒球系および血小板系細胞への 分化が促進された結果であると解釈されている。即

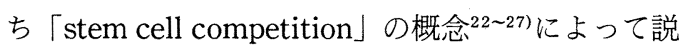
明可能である.「stem cell competition」の概念がヒ 卜にも当てはまることを最初に指摘したのは Smith \& Ekert ${ }^{8,9)}$ で，小児の白血病を含む悪性腫瘍 性疾患患者を対象として比較試験をおこない，へモ グロビン濃度を $14 \sim 18 \mathrm{~g} / \mathrm{dl}$ に維持して寛解導入療 法を行った方が $10 \sim 12 \mathrm{~g} / \mathrm{dl}$ に比し好中球の回復が 有意に早く, 感染症合併率は低く, 化学療法を中止 する頻度も小さい結果を得た。これらの成績を踏ま え, 過多輸血が成人急性白血病治療において果たす 役割を解明することを企図した。

本研究において過多輸血を行った対象は 12 歳から 76 歳に分布し，60歳以上が 8 例を占めたが，毎日の 輸血に耐えられなかったのは，2例のみで，それぞ れ $13.3 \mathrm{~g} / \mathrm{dl}, 13.9 \mathrm{~g} / \mathrm{dl}$ で輸血間隔を延長せざるを得 なかった。その他の症例ではよく耐えて正常域また はこれに近いへモグロビン濃度下で白血病の寛解導 入療法を実施することが出来た．過多輸血群の早期 死亡例は17例中 3 例でありその発現率は対照群16例 中 1 例との間に有意差はなかったし，死因にも著差 がなく高齢者の一部を除けば過多輸血は成人急性非 リンパ性白血病の治療に導入可能であることが判明 した。この際, 最初へモグロビン濃度を正常以上ま で増加させるための過多輸血期間に平均 $7.8 \pm 1.7$ 日 を必要としたが，これは白血病の治療成績や予後と は関係なかった。

過多輸血により，骨髄赤芽球比率は有意に低下し 末梢網赤血球数は減少したが，白血病細胞数，末梢 成熟顆粒球数及び血小板数は有意な変動を示さな かった。また,骨髄における幼若顆粒球比率も不変で あった，骨髄 CFU-C の測定は行わなかったが，白 血病細胞が存在するとコロニー形成を見ることは殆 どなくなる ${ }^{28)}$ ので, この面から過多輸血の効果を窺 うことは困難と考える.他方, 赤血球系造血の低下 分は残存正常顆粒球系細胞の増加か白血病細胞の増
加により補充される可能性があるが，過多輸血前後 のこれら両細胞系の比率には有意差がみられなかっ

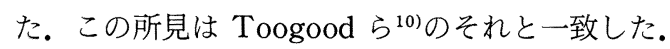

次に過多輸血前後の骨髄白血病細胞の LI につい て考察したい. 全体としては両平均値間には表 1 に 示した如く有意差はなかったが，14例中 7 例では前 值に比し後值が高值であった. Paton ら ${ }^{29)}$ の成績14 例中 9 例より低率であるとはいえ注目すべき所見と 考えられる. 過多輸血後 LI が増加した 7 例と不変 または減少した 7 例に区分して血液, 骨髄像を検討 したが各群平均值間に有意差はなかった。 LI 増加機 序として白血病細胞の DNA 合成時間の延長か, S 期白血病細胞の増加が考えられる. Toogood ら ${ }^{10}$ は 残存正常顆粒球系幼若細胞の増殖能の増加も否定し 得ないとしており, CFU-C の検討の必要性を指摘し ているが，この状況下ではコロニー形成能を測定す ることが困難であることは先に述べた通りである. 本研究で得られた結果から $\mathrm{S}$ 期正常顆粒球系細胞の 増加を否定することは困難であるが, 細胞形態像な どからその可能性は低いと考えたい。従来の白血病 細胞の cell kinetics の成績30)からみて DNA 合成時 間の延長の可能性は低いし，図 3 に示した如く大型 標識細胞が増加している所見からもその可能性は大 体否定出来るので, 過多輸血により一部の症例では $\mathrm{S}$ 期白血病細胞比率が高まったと考えるべきであろ う. Paton ら ${ }^{29)}$ 同様に推論しており，その原因と して過多輸血による骨髄の homeostasis の変化を あげている。

さて, 過多輸血群の治療成績であるが, 本研究は 無作為に区分し対照群を設けて行われた比較研究で はないが，その前後に同一施設に入院した背景因子 に有意差をみなかった症例を対照としたもので，過 多輸血を除けば寛解導入療法も支持療法も同一であ り背景因子も等しく, 通常の所謂 historical control より優れた対照群を持つと考えることが出来る，完 全寬解率には著差を認めなかったし，寬解持続期間 や生存期間にも有意差はなかったが, 図 4 において 過多輸血群が若干勝る傾向が窺われるので, 更に症 例数を増して検討する必要があると思われる.

著者らの所属する教室の茂木 ${ }^{31)}$ は初回治療で完全 寛解に導入できた症例の芽球の LI は平均 $6.9 \pm 0$. $7 \%$ で無効例の $4.9 \pm 0.7 \%$ に比して有意に高率であ ることをかつて報告した。同様の成績は多数報告さ れている ${ }^{32 \sim 34)}$. 今回の対照群では LI を 7 例で測定 
できたにすぎず， 7 例中完全寛解に入った 5 症例で は平均值 $5.1 \pm 3.3 \%$ で茂木の寛解例のそれと有意差 はなかった。これに対して過多輸血後 LI が増加し た 7 例では早期死亡例はなく，5例が完全寛解とな っており, 完全寛解率は $71.4 \%$ ，うち 1 例に 5 年生 存例がみられた。一方，LI が減少または不変にと どまった過多輸血群 7 症例の完全寛解率は $42.9 \%$ と 前者に比し低值であり，しかも早期死亡が 2 例に達

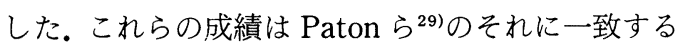
もので, 過多輸血後 LI 増加例は寛解導入成功率が 高いと考えることができる. LI の増加がS 期依存性 の抗白血病剤に対する感受性を増すためと推定さ れる。

過多輸血群で寛解導入療法開始時 LI が高いと薬 剤感受性が高まり根治の可能性もある一方, 残存す る正常造血細胞も $\mathrm{S}$ 期にはいるのでこれらも同時に より強く障害される可能性もある。まして過多輸血 下で CFU-C や CFU-Meg が活性化されているとす ると, かえって正常造血の回復をも同時に阻害する ことが考えられる．そこで寬解前後の正常造血の検 討が必要となる. 寬解導入療法開始後, 成熟顆粒球 数や血小板数の nadir に到達する期間は過多輸血群 で対照群に比し有意差はなかったものの長い傾向が あり，有熱率は低くかつ一部の症例であるが有熱期 間が短い傾向がみられた。 daunorubicin 投与量の多 少が関与する可能性は否定し得ないが, 寬解導入期 間中過多輸血のため多能性幹細胞から赤血球系へ分 化する分が抑えられ顆粒球系や血小板系へ分化する 分が多くなり，それが有熱期間の短縮につながった 可能性はある. 他方完全寛解例に於て成熟顆粒球数 が nadir から重症感染症に対する安全域である1, $000 / \mu 1$ をこえるまでの日数は過多輸血群と対照群 間で差はなかった．血小板数の回復期間にも両群間 で有意差を認めなかったものの, 過多輸血群ではそ の平均值は短い傾向があった，以上の傾向は寛解症 例特に LI 増加寛解例でより顕著な傾向がみられ た. 他方網赤血球の回復は過多輸血群で遅延する傾 向が瞡われたが，有意差はなかった。これらは更に 症例数を多くして検討すれば有意差となる可能性を 秘めるものと考光られる.

以上の成績は，ヒトでも「stem cell competition」 が存在する可能性を示唆し, 過多輸血により多能性 造血幹細胞から赤血球系への分化が抑制される反 面, 顆粒球系や血小板系への分化が増加した結果と 推定させる点で興味深い.「stem cell competition」 そ.白血病細胞の LI 増加との関係は不明であるが, 両者間に上記した如き関連が存在するので両者が全 く無関係であるとは考え難い.その関係の解明は今 後の検討に待ちたい.

\section{結語}

未治療成人 ANLL17例に過多輸血を行い, 輸血前 後の骨髄内芽球の LI を含め血液, 骨髄像の変化を 検討するとともに過多輸血下に寛解導入療法を行 い，その成績を過多輸血することなく同一の寛解導 入療法を施行した16例のそれと対比し次の結果を得 た。

(1) 過多輸血は患者に大きな負担を与えることなく ANLLの治療体系内に取り込むことが可能で あった.

(2) 過多輸血により末梢網赤血球数並びに骨䯣赤芽 球比率は有意に減少したが，末梢白血球数，芽球 数，血小板数及び骨髄芽球比率は有意に変化しな かった。

(3) 過多輸血前後に於て骨髄芽球の LI には全体と して有意の変動をみなかったが, 前值に比し後值 が増加したもの, 不変または減少したものが各 7 例であった。これら両群間で血液, 骨髄像に著差 はなかった. LI 増加は標識大型芽球の増加による もので, S 期細胞増加の結果と推定された。

(4) 過多輸血群と対照群間で完全宽解率, 完全寛解 期間, 生存期間に有意差はなかったものの, 後 2 者については過多輸血群で若干勝る傾向が窺われ た。

(5) 過多輸血群では LI 増加例の寛解率は不変及び 減少例のそれより高值であった。

（6）過多輸血群では寛解導入療法により成熟顆粒球 数及び血小板数が最低值に到達する期間に有意差 はなかったものの長い傾向があった，他方，寛解 例では最低值から成熟顆粒球が回復する期間には 差を見なかったものの, 血小板では過多輸血群で 短く有熱率が低值の傾向が窺われた。

(7) 上記の傾向は過多輸血群の中で LI 増加例でよ り顕著であった。

以上の結果には「stem cell competition」の関与 が推定されるものの, 症例数の関係もあって結論す ることは現時点では困難である. 更に症例数を増し で検討を続ける必要があると考える。 
稿を終るにあたり，御指導を賜わった前川正学長，御 校閲いただいた成清卓二教授および御協力いただいた教 室員各位に深謝する。

\section{文献}

1) Wiernik, P.H. : Spontaneous regression of hematologic cancers. Natl. Cancer Inst. Monogr., 44 : 35-38, 1976.

2) Han, T. and Sokal, J. E. : Spontaneous remission of leukemic lymphoproliferative disease. Cancer, $27:$ 586-595, 1971.

3) Ifrah, N., James, J., Viguie, F., Marie, J. and Zittoun, R.: Spontaneous remission in adult acute leukemia. Cancer, $56: 1187-1190$, 1985.

4) Diamond, L.K. and Luhby, A.L. : Pattern of "spontaneous" remissions in leukemia of childhood observed in 26 of 300 cases. Am. J. Med., $10: 238-239,1951$.

5) Firkin, F. C., Hays, E. F. and Cline, M. J. : Effect of hypertransfusion on granulopoiesis in bone marrow depression: Studies in the irradiated mouse. Brit. J. Haematol., 35 : 225231, 1977.

6) Smith, P. J., Jackson, C. W., Dow, L. W., Edwards, C. C. and Whidden, M. A. : Effect of hypertransfusion on bone marrow regeneration in sublethally irradiated mice. I. Enhanced granulopoietic recovery. Blood, $56: 52-57,1980$.

7) Smith, P. J., Jackson, C. W., Whidden, M. A. and Edwards, C. C.: Effect of hypertransfusion on bone marrow regeneration in sublethally irradiated mice. II. Enhanced recovery of megakaryocytes and platelets. Blood, 56 : 58-63, 1980.

8) Smith, P. J. and Ekert, H. : Evidence of stem-cell competition in children with malignant disease. Lancet, I : 776-779, 1976.

9) Toogood, I.R.G. and Ekert, H. : Controlled study of hypertransfusion during remission induction in childhood acute lymphocytic leukaemia. Lancet, II : 862-864, 1978.

10) Toogood, I. R. G., Ekert. H., Dobrostanski, B. and Waters, K. : Hypertransfusion in AML can increase the percentage of blasts in DNA synthesis. Leukemia Research, $2: 247-249$, 1978.

11) Uzuka, Y., Lion, S. K. and Yamagata, S. : Treatment of adult acute non-lymphoblastic leukemia using intermittent combination chemotherapy with daunomycin, cytosine arabinoside, 6-mercaptopurine and prednisolone-DCMP two-step therapy. Tohoku J. Exp. Med., 118 : 217-225, 1976.

12) Cooperative study group on leukemia and allied disorders : DCMP two-step therapy for acute myelogenous leukemia in adults. Jap. J. Clin. Oncol. $8:$ 133-140, 1978.

13) Yamada, K., Suzuki, H. and Kato, Y.: Phase III study of $\mathrm{N}^{4}$-Behenoyl-1- $\beta$-Darabinofuranosylcytosine in adult acute leukemia-BH-AC - DMP therapy- : Acta Haematol. Jpn. $43:$ 1080-1085, 1980.

14）木村喜代次，太田和雄，恒吉英彦：白血病の 化学療法上の二三の知見について. 癌, $48: 496$ 498, 1957.

15）村上博和，徳江 泰，塚田裕幸，横田 淳, 宮 脇修一, 野際英司, 高桑正道, 東雲正剛, 岩田 展明，梅枝定則，宮尾誠一，須田哲夫，小林紀 夫, 小峰光博, 土屋 純, 前川 正, 佐藤貞夫, 八代邦彦, 島野俊一：急性非リンパ性白血病 の治療経験。群馬医学，35：71-81，1981.

16）土屋 純： オートラジオグラフィー., 新版日 本血液学全書13巻, 血液学的検查 - 正常值, 丸 善, 東京, 1979, 261-276頁.

17) Bennett, J. M., Catovsky, D., Daniel, M., Flandrin, G., Galton, D. A. G., Gralnick, H. R. and Sultan,C.: Proposals for the classification of the acute leukaemias. FrenchAmerican-British (FAB) co-operative group. Brit. J. Haematol., 33 : 451-458, 1976.

18) Dreyfus, B. : Les rémissions de la leucémie aiguë. Rev. Hémat., $3: 29-47,1948$.

19) Bessis, M. et Dausset, J. : Êtude critique des rémissions au cours des leucémies aiguës traitées par exsanguino-transfusions. Rev. Hémat., 5 : 188-225, 1950. 
20) Bierman, H. R., Cohen, P., McClelland, J. N. and Shimkin, M. B.: The effect of transfusions and antibiotics upon the duration of life in children with lymphogenous leucemia. J. Pediat., 37 : 455-462, 1950.

21) Hayhoe, F. G. J. and Whitby, L.: The management of acute leukaemia in adults. Brit. J. Haematol., 1 : 1-19, 1954.

22) Harris, P.F., Harris, R. S. and Kugler, J. H. : Studies of the leucocyte compartment in guinea-pig bone marrow after acute haemorrhage and severe hypoxia: Evidence for a common stem-cell. Brit. J. Haematol., 12 : 419-432, 1966.

23) Hellman, S. and Grate, H. E.: Haematopoietic stem cells: Evidence for competing proliferative demands. Nature, 216:65-66, 1967.

24) Hellman, S. and Grate, H. E. : Enhanced erythropoiesis with concomitant diminished granulopoiesis in preirradiated recipient mice. Exp. Med., 127 : 605-612, 1968.

25) Metcalf, D. : The effect of bleeding on the number of in vitro colony-forming cells in the bone marrow. Brit. J. Haematol., 16 : 397-407, 1969.

26) Lawrence, J. S. and Craddock, C. G., Jr : Stem cell competition: The response to antineutrophilic serum as affected by hemorrhage. J. Lab. Clin. Med., 72 : 731-738, 1968.

27) Morley, A., Howard, D., Bennett, B. and Stohlman, F., Jr : Studies on the regulation of granulopoiesis II. Relationship to other differentiation pathways. Brit. J. Haematol., $19: 523-532,1970$.
28）宮尾誠一, 植竹 敏, 吉松 弘, 小峰光博, 土 屋純, 前川正：成人白血病における CFU-C と CSF・特に予後との関連において。 最新醫學, $34: 1023-1028,1979$.

29) Paton, C. M., Ekert, H., Toogood, I. R. G., Waters, K. D. and Dobrostanski, B. : Transfusion can change the labelling index in AML : Association of post-transfusion LI and remission status. Brit. J. Haematol., 46 : 157-160, 1980.

30) Tsuchiya, J. and Maekawa, T.: Cytokinetic studies on hematopoietic cells of the bone marrow. Acta. Haematol. Jpn., 36 : 641660, 1973.

31）茂木正毅：急性白血病細胞の増殖動態殊に ${ }^{3} \mathrm{H}$ $\mathrm{TdR}$ 標識率と DNA 合成時間に関する研究。 日血会誌, $40 ： 284-292,1977$.

32) Preisler, H. D., Azarnia, N., Raza, A., Grunwald, H., Vogler, R., Browman, G., Goldberg, J., Chervenick, P., Miller, K., Brennan, J., Winton, L., Joyce, R. and Gottlieb, A. : Relationship between the per cent of marrow cells in $\mathrm{S}$ phase and the outcome of remission-induction therapy for acute nonlymphocytic leukaemia. Brit. J. Haematol., 56 : 399-407, 1984.

33) Hart, J. S., George, S. L., Frei, E., III., Bodey, G. P., Nickerson, R. C. and Freireich, E. J. : Prognostic significance of pretreatment proliferative activity in adult acute leukemia. Cancer, 39 : 1603-1617, 1977.

34) Hillen, H., Wessels, J. and Haanen, C. : Bone-marrow-proliferation patterns in acute myeloblastic leukaemia determined by pulse cytophotometry. Lancet, I : 609-611, 1975. 


\title{
EFFECTS OF HYPERTRANSFUSION ON THE TREATMENT OF ADULT ACUTE NON-LYMPHOCYTIC LEUKEMIA
}

\section{SHOUGO SHINONOME, JUN TSUCHIYA*}

\author{
The Third Department of Internal Medicine, Gunma University \\ School of Medicine, Maebashi, 371, Japan \\ (Director: Prof. Takuji Naruse) \\ *College of Medical Care and Technology, \\ Gunma University
}

We studied 33 previously untreated adult patients with acute non-lymphocytic leukemia (ANLL) who were treated with induction chemotherapy between January 1979 to December 1981.

Seventeen adult patients with ANLL were treated with DCMP (daunorubicn, ara-c, 6mercaptopurine, prednisolone) or BHAC-DMP regimen following hypertransfusion (hypertransfusion group) and changes in the peripheral blood and bone marrow cells including the labeling index of leukemic blasts (LI) were studied during the treatment. As controls, 16 adults with ANLL with background factors similar to those of the hypertransfusion group were treated with the same regimen without hypertransfusion (control group). The results were: (1) Both peripheral reticulocyte and marrow erythroblast counts decreased significantly after hypertransfusion, but there were no changes in the counts of peripheral leukocytes, leukemic blasts and platelets or the percentage of leukemic blasts among the nucleated marrow cells. (2) As a whole, no significant change was noted in the LI after hypertransfusion, while in 7 patients (increase group) the LI clearly increased after hypertransfusion due to the rise in the number of labeled large blasts. This suggests an increase in the number of blasts in the $\mathrm{S}$ phase. In the remaining 7 patients (non-increase group), the LI decreased or remained unchanged after hypertransfusion. (3) There were no significant differences between the hypertransfusion and control groups in complete remission (CR) rate, the remission duration or the survival period. But the latter two periods tended to be longer in the hypertransfusion group. The $\mathrm{CR}$ rate of the increase group tended to be higher than the non-increase group. (4) In the hypertransfusion group, the period from the start of remission induction chemotherapy to reaching the nadir of mature granulocyte and platelet counts tended to be longer than in the control group. (5) In patients achieving $\mathrm{CR}$, the ratio of febrile days to days from the start of chemotherapy to reaching $\mathrm{CR}$ and the time period for recovery of platelet counts tended to be lower and shorter, respectively, in the hypertransfusion group than in the control group. This tendency was more evident is the increase group.

From these results, it appears that so-called stem cell competition may exist in human beings. Further study is required to evaluate the significance of hypertransfusion in the treatment of ANLL.

Key words: Acute non-lymphocytic leukemia. Hypertransfusion. Labeling index. Chemotherapy. 